\title{
Development of Hot Press Molding for HDPE Recycling and Process Characterization
}

\author{
Sabarudin Akhmad, Ida Lumintu \\ Industrial Enginering Department \\ University of Trunojoyo Madura \\ Bangkalan, Indonesia \\ sabarutm@gmail.com
}

\author{
Anis Arendra \\ Mechanical Enginering Dept \\ University of Trunojoyo Madura \\ Bangkalan, Indonesia \\ anis.arendra@trunojoyo.ac.id
}

\begin{abstract}
The 2nd generation HDPE Recycle Hot Press machine is the revamps of the first generation machine. The first generation hot press still has many shortcomings that make production results not optimal, such as porosity defects, limited product dimensions and the manual pressing process. The method used for the 2nd Generation HDPE Hot Press Recycle characterization is RAL23. Factors that have a significant effect on porosity defect are heating temperature factor. Combination of treatments that yield the smallest average porosity defect is $180^{\circ} \mathrm{C}$ heating temperatur, 3 minute holding time, and opening mold at temperatur $100^{\circ} \mathrm{C}$, average porosity defect reached 0 $\mathbf{m m}^{2}$. Factors that have a significant effect on flashing defect are factors heating temperatur, holding time, opening mold temperature. Combinations factor that yield the smallest average flashing defect is a combination of $150^{\circ} \mathrm{C}$ heating temperatur, 6 minute holding time, and opening mold at $85^{\circ} \mathrm{C}$, with an average flashing defect of $12.09 \mathrm{~g}$. Factors that have a significant effect on energy consumption are factors heating temperatur and the interaction of factor holding time. Treatment combinations that yield the smallest average energy consumption that is a combination of $150^{\circ} \mathrm{C}$ heating temperatur, 6 minute holding time, and opening mold at $85^{\circ} \mathrm{C}$ with average energy consumption of 0.4233 kwh.
\end{abstract}

Keywords—Hot Press Machine; HDPE; Porosity; Flashing

\section{INTRODUCTION}

Plastic waste processing technology is increasingly sophisticated. There are many innovations and the development of plastic waste treatment processes, ranging from extrusion processes, blow molding, injection, coating, and compression[1, 2, 3]. However, the development of plastic waste processing technology has not been able to suppress the high level of plastic waste that has increased every year. One of them is the type of plastic HDPE (High Density Polyethiylene) which is one type of plastic that is often found in everyday life $[4,5]$.

Plastics HDPE types that are often found in everyday life include the cap of mineral water, the oil packaging, household appliances and so on. Characteristics of HDPE plastic that are harder, stronger and more resistant to high temperatures make this type of plastic has its own advantages for recycling[5, 6, 7]. In addition the price of HDPE plastic scrap ranges between Rp. 5000 to Rp. 8000 per kilogram is still relatively cheap and easy to find[8]. If HDPE plastic waste treatment can be done well, it will provide considerable benefits.

The second generation HDPE Recycle Hot Press machine is the revamp of the first generation of Hot Press Recycle Plastic machine. In general, the working systems of both machine have no significant differences. The development that was carried out was replacing the mechanical jack with pneumatic piston. Then the mold dimensions were originally only $20 \mathrm{~cm} \times 10 \mathrm{~cm}$, revamp to $50 \mathrm{~cm} \times 30 \mathrm{~cm}$. In addition, the 2nd Generation HDPE Recycle Press tool is designed with high flexibility so that it is user friendly and easy maintenance

Plastic waste processing technology is an innovation to overcome the increasing plastic waste in the world. The technology used has also varied, ranging from work concepts and processing techniques. There are several ways of processing plastic waste, namely extrusion, blow molding, injection molding, compression molding, melt flow index and film maufacturer.

\section{Extrusion Molding}

The working principle of plastic waste processing by extrusion is by inserting liquid or solid plastic material continuously. But most are solid plastic that has been chopped or destroyed. The material included can be in the form of pellet powder, splinters or logs[9]. Extrusion machines use the concept of combining a single rotating screw in a horizontal horizontal cylindrical steel pipe[10, 11]. The rotating skurp will push the molten plastic material by the cylindrical pipe to the end of the nozzle as a place for the molten plastic to exit [12].

\section{Blow Molding}

Blow molding is a process of plastic processing that produces hollow objects in the final product. Examples are mineral water bottles, cooking oil bottles and so on. There are three ways of processing platinum by blow molding, namely extrusion blow molding, injection blow molding and stretch blow molding [13].

\section{Injection Molding}

In the injection process there are two ways and types of machines used are vertical injection machines and horizontal injection machines. The working principle of injection 
machines is almost the same as extrusion. First, the plastic collected in the hopper enters the cylindrical pipe that has been heated by the heating element. Inside the plastic cylinder pipe is melted by a heater that has been installed. Plastic seeds that have been melted are then injected until they come out through the nozzle into the desired mold $[14,15]$.

\section{Compression Molding}

The basic process of processing by using this method is heating the plastic material in the mold and then being pressurized to form the desired mold. Plastic material that melts due to the heat element will fill the cavity in the mold so that it will be solid. After the pressure has been maximal and the plastic material has melted, then cool the mold until the plastic material really hardens and forms the desired mold [16, $17,18]$.

\section{OBJECTIVE AND RESEARCH METHOD}

The aims of this study is to improve the desain quality of hot press machines and characterize the newly build machines. This study uses the dependent variable and independent variables.

\section{a. Independent Variable}

The independent variables of this study are:

\section{Heating temperature}

Variable heating temperature used is $150^{\circ} \mathrm{C}$ and $180^{\circ} \mathrm{C}$. Level determination of $150^{\circ} \mathrm{C}$ and $180^{\circ} \mathrm{C}$ based on previous research and also melting point of HDPE plastic itself.

\section{2. holding time}

Holding time is the time it hold at the specified tempereture. In this study, it took 3 minutes and 6 minutes.

\section{Opening mold temperature}

When opening the mold the specified temperature is $85^{\circ} \mathrm{C}$ and $100^{\circ} \mathrm{C}$.

\section{b. Dependent variable}

The dependent variable in this study is:

1. Porosity defects

2. Flashing defect

3. Energy consumption

\section{RESULT AND DISCUSSION}

The results of the study are presented in Tables I, III, V. Table I shows the results of porosity defect caracterization on engine parameter settings. Table III shows the results of the characterization of the flashing defects against the engine parameter settings. Table $\mathrm{V}$ shows the results of the characterization of energy consumption on the engine parameter settings.

Based on table II the analysis of variants for porosity defects, can be made a decision:

a. Factor a (Heating Temperature)
$\mathrm{P}$-value is 0.00450 .05 , so reject H0. There is a significant effect of heating temperature on porosity defects

\section{b. Factor b (Heating Time)}

The value of P-Value is $0.457>005$ so accept H0. There is no significant effect of heating time on porosity defects

c. C factor (opening temperature)

Value of P - Value $0.284>0.05$ so accept H0. There is no significant effect of the opening temperature on porosity defects

\section{d. Combination of a factor and factor $b$}

The P-value is 0.785> 0.05 so accept H0. There is no significant effect of heating temperature and heating time on porosity defects

\section{e. Combination of factors $a$ and $c$}

$\mathrm{P}$-value value $=0.256>0.05$ so accept $\mathrm{H} 0$. There is no significant effect of heating time and opening temperature on porosity defects

\section{f. Combination of factors $b$ and $c$}

Value of P-value $=0.785>0.05$ so accept H0. There is no significant effect of heating time and opening temperature on porosity defects

\section{g. A combination of factors $a, b$ and $c$}

The value of P-value $=0.734>0.05$ so accept $\mathrm{H} 0$. There is no significant effect of heating temperature, heating time and opening temperature on porosity defects

Based on table IV, analysis of variants for flashing defect, can be made a decision:

\section{a. Factor a (Heating Temperature)}

The value of P-value is 0.000 Sehingga 0.05 , so reject $\mathrm{H} 0$. There is a significant effect of heating temperature on flashing defect

\section{b. Factor b (Heating Time)}

Value of P-Value $0,000 \leq 0.05$ so reject H0. There is a significant effect of heating time on flashing defect

\section{c. C factor (opening temperature)}

The value of P-Value is 0.040 lak 0.05 so it rejects H0. There is a significant effect of the opening temperature on flashing defect

\section{d. Combination of a factor and factor $b$}

$\mathrm{P}$-value is $0.390>0.05$ so accept H0. There is no significant effect of heating temperature and heating time on flashing defect

\section{e. Combination of factors $a$ and $c$}

$\mathrm{P}$-value value $=0.179>0.05$ so accept H0. There is no significant effect of heating time and opening temperature on flashing defect

f. Combination of factors $b$ and $c$ 
P-value value $=0.462>0.05$ so accept $\mathrm{H} 0$. There is no significant effect of heating time and opening temperature on flashing defect

\section{g. A combination of factors $\mathrm{a}, \mathrm{b}$ and $\mathrm{c}$}

The value of $\mathrm{P}$-value $=0.333>0.05$ so accept $\mathrm{H} 0$. There is no significant effect of heating temperature, heating time and opening temperature on flashing defect

Based on table VI, the analysis of variants for energy consumption can be made a decision:

\section{a. Factor a (Heating Temperature)}

The value of P-value is 0.000 Sehingga 0.05 , so reject H0. There is a significant effect of heating temperature on energy consumption

\section{b. Factor b (Heating Time)}

Value of P-Value 0.099> 0.05 so accept H0. There is no significant effect of heating time on energy consumption

\section{c. C factor (opening temperature)}

P-Value value of $0.0568>0.05$ so that it accepts H0. There is no significant effect of the opening temperature on energy consumption

\section{d. Combination of a factor and factor $b$}

The P-value is 0.322> 0.05 so accept H0. There is no significant effect of heating temperature and heating time on energy consumption

\section{e. Combination of factors $a$ and $c$}

P-value value $=0.208>0.05$ so accept $\mathrm{H} 0$. There is no significant effect of heating time and opening temperature on energy consumption

\section{f. Combination of factors $b$ and $c$}

$\mathrm{P}$-value $=0,000 \leq 0.05$ so reject $\mathrm{H} 0$. There is a significant effect of heating time and opening temperature on energy consumption

\section{g. A combination of factors $\mathrm{a}, \mathrm{b}$ and $\mathrm{c}$}

$\mathrm{P}$-value value $=1>0.05$ so accept $\mathrm{H} 0$. There is no significant effect of heating temperature, heating time and opening temperature on energy consumption

TABLE I. DATA TABUlation For POROSITY DEFECT

\begin{tabular}{|c|c|c|c|c|}
\hline \multicolumn{5}{|c|}{ Flashing Defects } \\
\hline \multirow{4}{*}{$\begin{array}{l}\text { heating } \\
\text { temperature } \\
\left({ }^{\circ} \mathrm{C}\right)\end{array}$} & \multicolumn{4}{|c|}{ heating time (minute) } \\
\hline & \multicolumn{2}{|c|}{3} & \multicolumn{2}{|c|}{6} \\
\hline & \multicolumn{4}{|c|}{ opening temperature } \\
\hline & 85 & 100 & 85 & 100 \\
\hline \multirow{3}{*}{150} & 11 & 13 & 2 & 6 \\
\hline & 17 & 0 & 28 & 6 \\
\hline & 4 & 3 & 9 & 11 \\
\hline \multirow{3}{*}{180} & 0 & 0 & 0 & 4 \\
\hline & 3 & 0 & 3 & 4 \\
\hline & 1 & 0 & 0 & 0 \\
\hline
\end{tabular}

TABLE II. ANALYSIS OF VARIANCE FOR POROSITY DEFECT

\begin{tabular}{|l|c|c|c|c|c|}
\hline \multicolumn{1}{|c|}{ Source } & Df & Adj SS & $\begin{array}{c}\text { Adj } \\
\text { MS }\end{array}$ & $\begin{array}{c}\text { F- } \\
\text { value }\end{array}$ & $\begin{array}{c}\text { P- } \\
\text { value }\end{array}$ \\
\hline Factor a & 1 & 384.00 & 384.00 & 11.05 & 0.004 \\
\hline Factor b & 1 & 20.17 & 20.167 & 0.58 & 0.457 \\
\hline Factor c & 1 & 42.67 & 42.667 & 1.23 & 0.284 \\
\hline Factor a * Factor b & 1 & 2.67 & 2.667 & 0.08 & 0.785 \\
\hline Factor a * Factor c & 1 & 48.17 & 48.167 & 1.39 & 0.256 \\
\hline Factor b * Factor c & 1 & 2.67 & 2.667 & 0.08 & 0.785 \\
\hline $\begin{array}{l}\text { Factor a * Factor b * } \\
\text { Factor c }\end{array}$ & 1 & 4.17 & 4.167 & 0.12 & 0.734 \\
\hline Error & 16 & 5556.00 & 34.75 & & \\
\hline
\end{tabular}

TABLE III. DATA TABULATION FOR FLASHING DEFECT

\begin{tabular}{|l|c|c|c|c|}
\hline \multirow{4}{*}{$\begin{array}{l}\text { Flashing Defects } \\
\text { temperating } \\
\left({ }^{\circ} \mathbf{C}\right)\end{array}$} & \multicolumn{4}{|c|}{ heating time (minute) } \\
\cline { 2 - 5 } & \multicolumn{3}{|c|}{$\mathbf{3}$} & \multicolumn{2}{c|}{$\mathbf{6}$} \\
\cline { 2 - 5 } & \multicolumn{4}{|c|}{ opening temperature } \\
\cline { 2 - 5 } 150 & $\mathbf{8 5}$ & $\mathbf{1 0 0}$ & $\mathbf{8 5}$ & $\mathbf{1 0 0}$ \\
\hline \multirow{3}{*}{180} & 21.460 & 20.435 & 12.602 & 14.460 \\
\cline { 2 - 5 } & 17.417 & 44.985 & 10.349 & 15.532 \\
\cline { 2 - 5 } & 12.357 & 29.911 & 13.341 & 21.737 \\
\hline & 37.809 & 53.892 & 30.458 & 41.026 \\
\cline { 2 - 5 } & 56.039 & 44.971 & 37.551 & 35.793 \\
\cline { 2 - 5 } & 48.592 & 48.360 & 28.697 & 28.681 \\
\hline
\end{tabular}

TABLE IV. ANALYSIS OF VARIANCE FOR FLASHING DEFECT

\begin{tabular}{|l|c|c|c|c|c|}
\hline \multicolumn{1}{|c|}{ Source } & Df & Adj SS & $\begin{array}{c}\text { Adj } \\
\text { MS }\end{array}$ & $\begin{array}{c}\text { F- } \\
\text { value }\end{array}$ & $\begin{array}{c}\text { P- } \\
\text { value }\end{array}$ \\
\hline Factor a & 1 & 2758.11 & 2758.11 & 61.87 & 0.000 \\
\hline Factor b & 1 & 888.18 & 888.18 & 19.93 & 0.000 \\
\hline Factor c & 1 & 222.72 & 222.72 & 5.00 & 0.040 \\
\hline Factor a Factor b & 1 & 34.83 & 34.83 & 0.78 & 0.390 \\
\hline Factor a * Factor c & 1 & 88.00 & 88.00 & 1.97 & 0.179 \\
\hline Factor b * Factor c & 1 & 25.32 & 25.32 & 0.57 & 0.462 \\
\hline $\begin{array}{l}\text { Factor a * Factor b * } \\
\text { Factor c }\end{array}$ & 1 & 44.47 & 44.47 & 1.00 & 0.333 \\
\hline Error & 16 & 4774.83 & & & \\
\hline
\end{tabular}

TABLE V. DATA TABULATION FOR ENERGY CONSUMTION

\begin{tabular}{|c|c|c|c|c|}
\hline \multicolumn{5}{|c|}{ Flashing Defects } \\
\hline \multirow{4}{*}{$\begin{array}{l}\text { heating } \\
\text { temperature } \\
\left({ }^{\circ} \mathrm{C}\right)\end{array}$} & \multicolumn{4}{|c|}{ heating time (minute) } \\
\hline & \multicolumn{2}{|c|}{3} & \multicolumn{2}{|c|}{6} \\
\hline & \multicolumn{4}{|c|}{ opening temperature } \\
\hline & 85 & 100 & 85 & 100 \\
\hline \multirow{3}{*}{150} & 0.60 & 0.47 & 0.50 & 0.52 \\
\hline & 0.56 & 0.44 & 0.42 & 0.55 \\
\hline & 0.69 & 0.52 & 0.45 & 0.57 \\
\hline \multirow{3}{*}{180} & 0.69 & 0.61 & 0.63 & 0.70 \\
\hline & 0.73 & 0.61 & 0.59 & 0.71 \\
\hline & 0.72 & 0.59 & 0.59 & 0.68 \\
\hline
\end{tabular}

TABLE VI. ANALYSIS OF VARIANCE FOR ENERGY CONSUMTION

\begin{tabular}{|l|c|c|c|c|c|}
\hline \multicolumn{1}{|c|}{ Source } & Df & Adj SS & Adj MS & F-value & $\begin{array}{c}\text { P- } \\
\text { value }\end{array}$ \\
\hline Factor a & 1 & 0.141076 & 0.141076 & 180.09 & 0.000 \\
\hline Factor b & 1 & 0.002400 & 0.002400 & 3.06 & 0.099 \\
\hline Factor c & 1 & 0.000267 & 0.000267 & 0.34 & 0.568 \\
\hline Factor a * Factor b & 1 & 0.000817 & 0.000817 & 1.04 & 0.322 \\
\hline Factor a Factor c & 1 & 0.001350 & 0.001350 & 1.72 & 0.208 \\
\hline Factor b * Factor c & 1 & 0.062017 & 0.062017 & 79.17 & 0.000 \\
\hline $\begin{array}{l}\text { Factor a * Factor b * } \\
\text { Factor c }\end{array}$ & 1 & 0.000000 & 0.000000 & 0.000000 & 1.000 \\
\hline Error & 16 & 0.012533 & 0.000783 & & \\
\hline
\end{tabular}




\section{CONCLUSION}

Factors that have a significant effect on porosity defects are factor a (heating temperature). While the combination treatment that produces the smallest average porosity defect is a combination of 1803100 means using a heating temperature of $180^{\circ} \mathrm{C}$, heating time of 3 minutes and an opening mold at temperature $100^{\circ} \mathrm{C}$ with an average porosity defect of $0 \mathrm{~mm} 2$. In addition, all combinations of porosity defect testing are not significantly different.

Factors that have a significant effect on flashing defect are factors a (heating temperature), b (heating time), and $\mathrm{c}$ (opening temperature). While the combination treatment that produces the smallest average flashing defect is a combination of $150^{\circ} \mathrm{C}$ heating temperature 6 minutes heating time and opening mold at temperatur $85^{\circ} \mathrm{C}$, combination $150^{\circ} \mathrm{C}$ heating temperature, 6 minutes heating time $100^{\circ} \mathrm{C}$ opening temperature and combination $150^{\circ} \mathrm{C}$ heating temperature 3 minutes heating time $85^{\circ} \mathrm{C}$ opening temperature with the smallest average flashing defect $12.0973 \mathrm{~g}$.

Factors that have a significant effect on energy consumption are factors a (heating temperature) and the interaction of factor bc (heating time and opening temperature). While the combination treatment that produces the lowest average energy consumption is a combination of $150^{\circ} \mathrm{C}$ heating temperature 3 minutes heating time and $100^{\circ} \mathrm{C}$ opening temperature and combination $150^{\circ} \mathrm{C}$ opening temperature 6 minutes heating time $85^{\circ} \mathrm{C}$ opening temperature. with the smallest average energy consumption $0.4233 \mathrm{kwh}$.

\section{REFERENCES}

[1] T.L. Szabo, Introduction to plastics Recycling. 2005

[2] S. Corn and C. Wong, A Study of Plastic Recycling Supply Chain 2010 A Study of Plastic Recycling Supply Chain, no. October. 2010.

[3] B.A. Hegberg, G.R. Brenniman, and W.H. Hallenbeck, "Mixed Recycling Plastics Technology," Waste Manag.

[4] H. Hamod, "Suitability of recycled HDPE for 3D printing filament," Arcada University of Applied Science Degree, 2014.
[5] J.Y. Tong, N.R. Royan, Y. Ng, M.A. Ghani, and S. Ahmad, "Study of the Mechanical and Morphology Properties of Recycled HDPE Composite using Rice Husk Filler," Adv. Mater. Sci. Eng., vol. 2014, pp. 1-10, 2014.

[6] Y. Lei, Q. Wu, and Q. Zhang, "Morphology and properties of microfibrillar composites based on recycled poly (ethylene terephthalate) and high density polyethylene," Compos. Part A Appl. Sci. Manuf., vol. 40, no. 6-7, pp. 904-912, 2009.

[7] P.O. Tawiah, P.Y. Andoh, and F. Nyarko, "Characterization of Recycled Plastics for Structural Applications," vol. 5, no. 6, pp. 259-267, 2016.

[8] A. Arendra and S. Akhmad, "Rancang Bangun Mesin Hot Press untuk Recycle Plastik Hdpe dan Karakterisasi Pengaruh Temperatur Pemanasan Waktu Pemanasan dan Temperatur Pembukaan terhadap Cacat Flashing Cacat Warpage dan Konsumsi Energi Pencetakan," J. Ilm. REKAYASA, vol. 10, no. 2, pp. 108-115, 2017.

[9] J.M.A. Jaff, D.A. Abdulrahman, Z.O. Ali, K.O. Ali, and M.H. Hassan, "Design and Fabrication Recycling of Plastic System," vol. 7, no. 5, pp. 1471-1486, 2016.

[10] J. Musil, "Investigation of Die Drool Phenomenon during HDPE Melt Extrusion," Tomas Bata University, 2012.

[11] H. Valkenaers, F. Vogeler, E. Ferraris, a Voet, and J.-P. Kruth, "A novel approach to additive manufacturing: screw extrusion 3D-printing," 4M Conf., no. c, pp. 235-238, 2013.

[12] O. Lužanin, D. Movrin, and M. Plan, "Experimental Investigation of Extrusion Speed and Temperature Effects on Arithmetic Mean Surface Roughness in Fdm-," J. Technol. Plast., vol. 38, no. 2, pp. 179-190, 2013 .

[13] K. Giridharreddy, K.R.M. Tech, and D. Ph, "Blow Mould Tool Design and Manufacturing Process for 1 litre Pet Bottle," J. Mech. Civ. Eng., vol. 8, no. 1, pp. 12-21, 2013.

[14] M.J. Mutheu, "UNIVERSITY OF NAIROBI Design and Fabrication of an Injection Moulding Machine by," 2015.

[15] W. Chen, C. Huang, and C. Huang, "Finding efficient frontier of process parameters for plastic injection molding," 2013.

[16] A.A. Shamsuri, "Compression Moulding Technique for Manufacturing Biocomposite Products," Int. J. Appl. Sci. Technol., vol. 5, no. 3, pp. 2326, 2015.

[17] E. Kelly, E. Victor, and A. Samuel, "Design and Fabrication of Compression Molding Machine for Plastic Waste Recycling in Nigeria Introduction :," vol. 3, no. 11, pp. 1-20, 2016.

[18] B.S. Kumar and S. Balachandar, "A Study on the Influence of Hot Press Forming Process Parameters on Flexural Property of Glass/PP Based Thermoplastic Composites Using Box-Behnken Experimental Design," ISRN Mater. Sci., vol. 3, no. 4, pp. 1-6, 2014. 